\title{
AN APPRAISAL OF THE IMPACT OF ISLAMIC CO-OPERATIVE SOCIETIES ON SOCIO-ECONOMIC DEVELOPMENT IN SOME SELECTED STATES IN NIGERIA
}

\author{
Aminu Abdulrahim Olayinka \\ Accountancy Department \\ Mai Idris Alooma Polytechnic, Geidam \\ Yobe State, Nigeria \\ E-mail: aminu.abdulrahim68@gmail.com \\ Dr. Abdul Fattah Abdul Ganiy \\ Department of Accountancy \\ Federal Polytechnic Kaura Namoda \\ Zamfara State, Nigeria \\ Murtala Sirajo \\ Department of Accounting \\ Gombe State University, Gombe \\ Gombe State, Nigeria
}

\begin{abstract}
This study assessed the impact of Islamic Co-operatives Societies (ICSs) theoretically, legally and practically on Socio-Economic Development in Nigeria and consider its establishment in our various conventional interest-based economy community, which contradicts the ideals of Islamic principles of finance. The research was carried out within the general framework of Islamic financial principles and precepts. The research work focused on the needs of financing a large and growing Muslims community in line with their Islamic tenets thereby concentrating on the feasibility of adopting suitable ICS's modus operandi for the Muslim Community. It also studies the current realities of the ICSs being practiced in Nigeria from the perspective of the theories of Islamic financial system. Within this spectrum the operations and functions of registered Islamic cooperative societies in Adamawa Gombe, Kwara, and Zamfara States were reviewed. The study examined the key role of ICSs in an economy in fulfilling the microfinance needs of Muslims community, and find out that ICSs is a viable alternative solution to the conventional cooperative models and also alternative measure with potentiality to alleviate poverty. The study is limited in scope in a sense that it is not a comparative study of Islamic financial system with doctrines of other religions, ideologies and systems.
\end{abstract}

Keywords: Cooperative Society, ICSs, Conventional, Poverty, Socio-Economic.

JEL Classification Codes: D6, F63, R51, Q01, P13.

\section{INTRODUCTION}

The history of Muslims and Islam in Nigeria is as old as the country, the majority of the adherent of the religion are predominantly based in the Northern part of the country and a sizable number in the West with significant very low adherents in the East and South-South region of the country. However, the financial landscape has been predominantly Western, that is, financial transactions 
that are based on the conventional financial system from banks to insurance and capital market instruments.

In Nigeria, the records have it that Cooperative Societies started locally with the concepts of Esusu, Isusu, Osusu, Adashi, Dashi, Ajo etc, much earlier than the nineteenth century. Today, Cooperatives have developed strongly and indeed come to stay as alternative to Banking, a way in which people of common interest come together to chart ways of helping themselves, without having to pay much to obtain benefits from the Cooperative Societies. It has inculcated financial discipline among many people in the Society who ordinarily had poor savings culture. People who are members of Cooperative Societies now resort less to banks for loans, and this is a good development in any Economy. Economic hardship brought on people by political instability, natural disaster, conflicts, health crisis, poor wages or financial system turbulence led to the establishment of cooperative societies (Azeez \& Salako, 2007).

Islam encourages cooperation in all that lead to righteousness and piety, but the conventional cooperative societies are not acceptable in Islam. One major reason for the unacceptability of this system is the existence of interest (riba). Over the years, the Muslims in Nigeria had no choice than to use the conventional financial instruments for their day-to-day financial and business needs because there were no alternatives. But as the awareness grew within the community on the need to structure their financial transactions in line with their religious beliefs and to jettison riba - interest bearing transactions, the community had to create certain alternatives themselves.

One of such alternative is Islamic co-operative societies (ICSs), which affords individual to make contributions and get loans from the pull of funds without having to pay interest on the loan. Obviously, it is allowed in Islam to give loan without interest. What is forbidden is loan with interest (Q2:245, Q5:12, Q57:11, Q64:17, Q73:20). Islamic cooperative society's model serves as a smart way of avoiding riba (interest) among the Muslims, thus creating opportunities to have funds for their business growth in a way that is consistent with their beliefs.

\section{Problem Statement}

Poverty is the oldest and yet unresolved social problem, and despite numerous policy and various socio-Economic models adopted by local, national, international agencies and government, poverty reduction and inclusive economic growth remains a key challenge particularly in Nigeria and developing countries. Those policy measures seem not to be yielding the expected results since there is still low level of economic growth and high level of poverty. It has also been confirmed that the cooperative is the best financial institution useful for the eradication of poverty in any given society. Fortunately, despite the flourish and involvement of the conventional cooperatives in the poverty alleviation programs organized by various governments, there is still persistence in the increase of poverty incidence in Nigeria. Many people have been victims of insomnia, hypertension and stroke due to bankruptcy resulting from loan's interest rate from money-lenders who wear unsympathetic outlook and do not care for the borrowers. Therefore, this inability of those various measures and involvement of the conventional cooperatives to alleviate poverty in Nigeria call for alternative measure with potentiality to alleviate poverty, and that measure is suggested to be the use of ICSs, because it is based on equity participation non-interest financing and used for financing assets like real estates and venture capital financing. Capitalism or socialism economic system has proved to be failures for centuries, the only solution to the present predicament is Islamic economic system (Yusuf \& Ahmad Razimi, 2017). This paper examines the impact of the Islamic cooperative 
societies (ICSs) in social uplifting of a society. Onakoya and Onakoya (2013) posited how ICSs, can be used to alleviate poverty and maintain sustainable development in Nigeria. The study showed that Islamic cooperative societies in concert with the right fiscal and monetary policies framework will contribute positively to alleviating poverty in Nigeria.

\section{Objective of the Study}

The majority of the adherent of the Islamic religion are predominantly based in the Northern part of the country and a sizable number in the west. Unfortunately the economy of the country interest based. This contradicts the ideals of Islamic principles of finance. The objective of this research work is to critically assess the economic impact of ICSs theoretically, legally and practically in the context of Nigeria with a view to adopt best practice for Nigeria Muslim community to promote socio-economic justice. Therefore, the research work will be concentrating on the feasibility of adopting suitable ICSs modus operandi for social uplifting of the society.

\section{Justification of the Study}

Twice in the recent times, Nigeria has had a fair share of economic recession due to Covid-19 pandemic and its heavy reliance on crude-oil as the main source of income generating potential. This was largely caused by the 'glut' in the crude oil prices in the world market. Hence, there is need for strong institutions that are effective and capable of supporting the opportunities inherent in the ICSs systems. Also, the capacity of a country to drive the process of economic diversification anchors on its imperativeness to fast-tract the process of capital accumulation through cooperative societies.

The result of this research work will be of immense benefits to policy makers in Nigeria in the current efforts to eradicate poverty. It will also assist the non-governmental organizations efforts to attain the 2030 Agenda for sustainable development goal. Such goals include provision of food security to the poor. Furthermore, individuals and the society at large will also benefit from this research work. The study will throw more lights on the operational principles of the Islamic cooperative societies. It will also be used as a reference document in the area of cooperative research with respect to Islamic cooperative societies in selected states and the country at large.

\section{LITERATURE REVIEW}

A Cooperative can be defined as an autonomous and voluntary association of people that come together to pool their resources for business, economic, social and cultural welfare improvement (Nwagbara, 2018).

A Cooperative Society is a Voluntary Association of Individuals united by a common bond, who have come together to pursue their economic goals for their own benefits (Section 57, Nigerian Cooperative Societies Act, LFN 2004).

Kareem, Arigbabu, Akintaro, and Badmus (2012), defined Cooperative society as a voluntary association of people, engaging in a democratically controlled business organization, operating at cost which is owned, capitalized and controlled by patrons as users, sharing risks and benefits in proportion to their participation to achieve a common economic goal. The establishment of cooperative society is important to help members in obtaining credit in an easy way unlike in the banking sector that require collateral and other complicated documents. 
The main objective of cooperative societies is to provide financial support to the members. Nobody joins a cooperative society for fun but to earn profit and get support in time of financial difficulty. People come forward as a group, pool their individual resources, utilize them in the best possible manner, and derive some common benefit out of it. To achieve the objective of the cooperative, money is required. To obtain cash, members could subscribe for shares, which could be paid for by small weekly amounts. These shares formed the capital of the cooperative. This capital is used to purchase goods at low cost and to sell them to its members at retail price. Any surplus made would be distributed to the members according to their use of the store. This is after paying the capital providers a small fixed sum and retaining some for the development of the society. For example retaining 2.5\% for the education of the member. Abubakar (2020) opined that a cooperative society is basically an organization for the establishment of a self-supporting community, owned by and operated for the benefit of those using its services

Islamic cooperative society is a conversion of conventional cooperative through an approach that is in line with Shariah. The establishment of ICS is basically using the concept of Shirkah Mufawadah in which all parties involved contribute fund in the same portion as well as equally participate in managing the organization and the profit and loss are shared among the members. Each member has equal vote and opportunity to express idea and opinion (Irfan Beik \& Indah Purnamasari, 2011).

\section{Comparison between Islamic and Conventional Cooperatives}

\section{Islamic Cooperative society}

- Driven by profit and social motives.

-The operation is based on Shariah and legal

Rules prevailing in the countries.

- The profit earned from various Islamic modes of financing.

(Irfan Beik \& Indah Purnamasari, 2011).

In Nigeria, at the moment, there are various Islamic co-operative society groups that are doing well in this regard and in line with the teaching of Islam. Among the most important teachings of Islam for establishing justice and eliminating exploitation in business transactions, is the prohibition of all sources of unjustified enrichment and the prohibition of dealing in transactions that contain excessive risk or speculation (Ahmad \& Ahmad, 2008). The modus operandi of Islamic Cooperative is very unique and if followed to the letter it has and will continuously ensure that Muslims and Non-Muslim who are averse to taking interest bearing loans can have an alternative to funding their personal and business needs in a way that is consistent with their faith and interest. ICSs make use of some Islamic Financial Products (IFPs) to make both the cooperatives and their members fulfill their religious obligations and recommendations to improve them socially and economically (Ajani \& Adebayo, 2018).

Below are some of the highlights on how an Islamic co-operatives operates:

1. People of like-minds come together to float a co-operative society.

2. The body is registered with the appropriate authority

3. The members elect leaders among themselves to chat the course of the organizations.

4. Each member commit to a fixed or variable monthly contributions, in some cases the society can charge an annual membership fee. 
5. The pull of funds will be administered by the society and it's invested in a viable and Halal venture - returns from such investments are used to run the day-to-day activities of the society and at the end of the year dividend are paid to the members based on their contributions.

6. Each member of the society can apply for an interest free loan based on the total value of the contributions in their account, this varies across societies, in some cases it can be up to $100 \%$ or more of the members' contributions. The payback period for the loan also varies from 6 to 12 months depending on the society and their financial capability.

7. The society also help her members in purchases of house-hold items. These items are sold to the members at a mark-up fee using the Murabaha concept of Islamic finance. By this approach members have the opportunity of spreading the payment over a given period of time and the society also make profit. Thus creating a symbiotic relationship where both parties wins as opposed to the interest bearing facilities where the banks are the winners at all times. ICSs's model has the advantages of promoting and circulating wealth among the people through risk and return sharing (El-Mesawi, 2006, Chapra, 2008).

8. The society can also engage in a joint purchase of landed property using the economy of scale to negotiate for the property. The property is then sold to the members at a marked up profit payable over a period of time.

These are a few highlights of the modus operandi of how an ICS operates. To break off from the riba dominated financial transactions, there is need to have as many Islamic co-operative societies as possible. Islamic cooperative societies will also spouses a philosophy of providing finance on a fair and more equitable basis, which, in the long term, would promote socio-economic development in the society at large (Mohammed \& Hasan, 2008).

Islamic co-operative societies (ICS) could be formed to satisfy personal financial needs of members and to provide interest free loans to meet certain contingencies. The need for such organizations is present both in rural and urban settings. In the absence of such interest free alternatives, people are forced to borrow on interest from traditional, as well as non-traditional sources. The prospective demand for the ICS in Nigeria is certain and difficult to measure.

According to Islam (2017) Islamic financial system was practiced predominantly in the Muslim world. There are more than 110 million Muslims in Nigeria, Islam being the largest religion representing $55 \%$ of the population. The Nigerian Muslim community is majorly concentrated in the northern part of the country, and it is ethnically and linguistically diverse, and geographically scattered all over the country, making the demand for Islamic financial products encouraging. Nevertheless, there exist many ICSs established by various Muslim communities either in well-established public and private organizations or in communities that have zeal for Islamic co-operative and want to do away from interest bearing co-operative.

According to Dusuki and Abozaid 2007, mobilizing of resources for micro, small and medium enterprise development without violating Islamic financial principles and ultimately leads to realization of the aqasid al shariah.

\section{Model for Islamic Co-operative Societies (ICSs) in Nigeria}

The concept of ICSs as it is being practiced in some developed and developing countries are more of being a microfinance institution, which assists members in term of personal finance and business finance. It is not considered as a mere society that grants loans to members to meet domestic needs only. Based on the principles guiding Islamic finance, granting loan for businesses is not 
encouraged, the members of the cooperative can only be granted benevolent loan for personal use and the repayment of the loan shall be strictly based on shariah principles and rulings. Any member that needs finance for business partners with cooperative and the principles of profit and loss sharing are applied. The ultimate goal of Islamic cooperative model is the maximization of social benefits as opposed to profit maximization. This can be achieved through the creation of healthier financial institutions that provide effective financial services at grass root. Some authors argue that Islamic co-operative, if inserted in a new paradigm, could be a viable alternative solution to the conventional cooperative models and also alternative measure with potentiality to alleviate poverty. Islamic microfinance is basically a microfinance that employs Islamic finance principles in providing financial services to the poor (Onakoya \& Onakoya 2013).

\section{Study Area}

\section{METHODOLOGY}

The population of this study comprised Islamic cooperative societies in Adamawa, Gombe, Kwara and Zamfara State Nigeria.

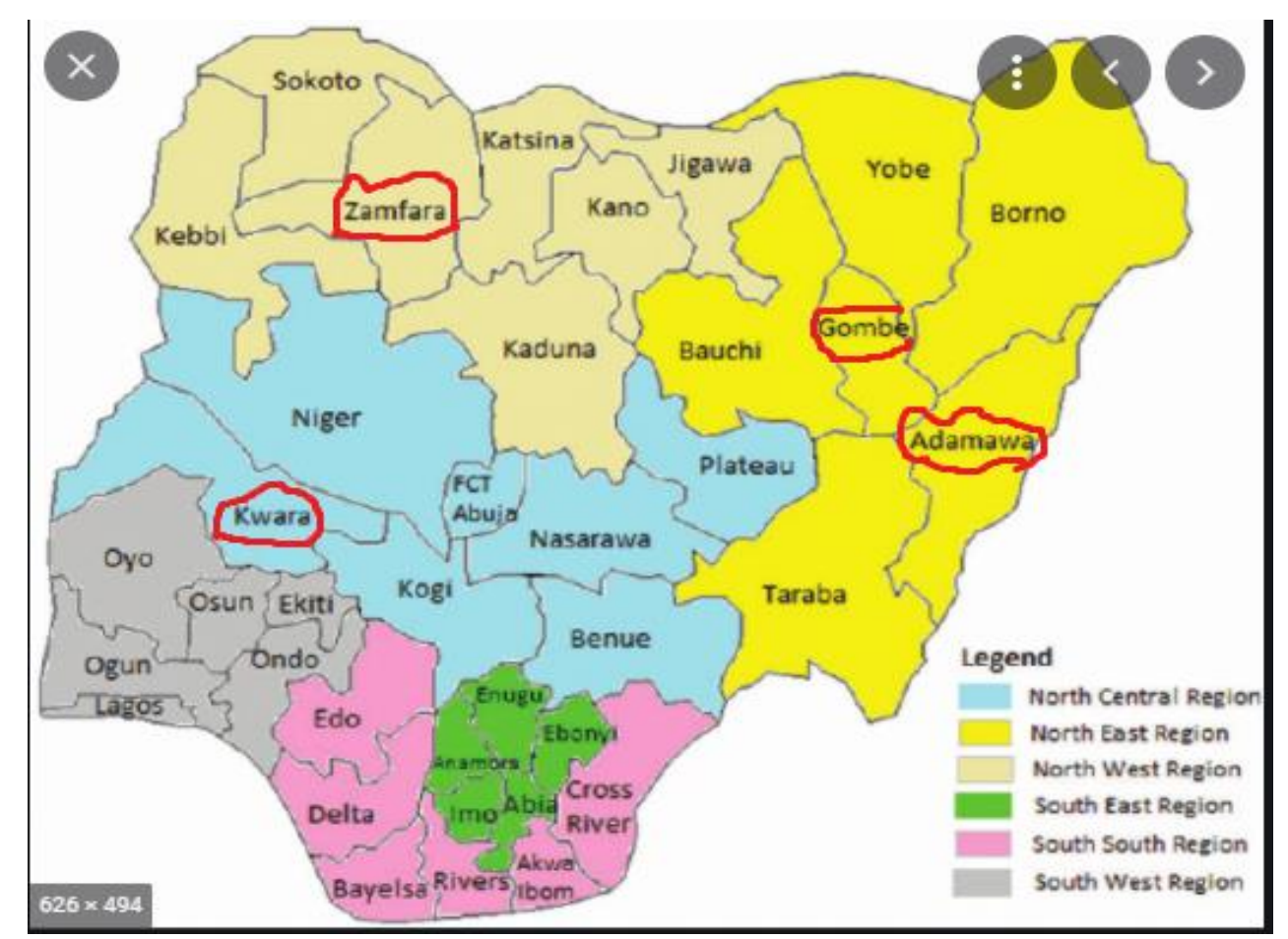

Figure 1. Map of Nigeria showing the selected state; Adamawa, Gombe, Kwara and Zamfara

Based on the nature of the topic, qualitative research was conducted, thus the design for this study was survey. Interviews and questionnaires were used to gather information. Interviews were structured in order to make comparisons among interviewees. The interview questions were structured and all the participants were asked the same questions, officials of the Cooperative Societies have their own set of similar questions. During interviews the researcher take notes and also record the proceedings of the interview. Interviews with the Islamic cooperative managers, Implementing Agency representatives, of existing ICSs were conducted in Adamawa, Kwara, Gombe and Zamfara States. Questionnaires were administered on the existing Participants in Islamic cooperatives societies in those four States. 
Secondary data in the form of documentation (Memorandum and article of association, society bye-laws, Annual Reports, Framework Implementation Manual, etc.) were also used to get information, they were reviewed to get information on the activities and operations of the recent Islamic cooperative societies and their achievements.

\section{RESULTS AND DISCUSSION}

Cooperative Societies are regarded as vehicle to fight poverty according to Kotze in Swanepoel (1992). As El-Mesawi (2006) and Chapra (2008) identify that ICS's model has the advantages of promoting and circulating wealth among the people through risk and return sharing, making it an instrument for sustainable economic development. For sustainable economic development, the root cause of poverty needs to be analysis as well. Poverty is about quality of life, power and access to resources as it is about income (Graaf 2003). Blewitt, (2008) stated that there is no magic formula for economic development and no easy reformist solution to poverty and that contrary to dominant practice by conventional economic system, development ought to be what human communities do to themselves rather than what is done to them by the state or agencies.

This shows that people need to do what they want to do in terms of the needs of the communities and not something that is enforced. As defined by Kareem, et al (2012), Cooperative society is a voluntary association of people, engaging in a democratically controlled business organization, operating at cost which is owned, capitalized and controlled by patrons as users, sharing risks and benefits in proportion to their participation to achieve a common economic goal. Furthermore, Irfan Beik and Indah Purnamasari, (2011) Identify that in ICSs, each member has equal vote and opportunity to express idea and opinion. Base on the relevant literature stated above and many others, Islamic cooperative society will have positive impact on the sustainable economic development and poverty alleviation of the communities. ICSs are a powerful and effective tool for wealth creation and investment. Many Muslim heard about, but only few understand them and the immense opportunities they offer. ICSs have the capacity to reduce poverty, enhance job creation, encourage savings, reduce business risk and improve national productivity.

In Nigeria Cooperative Societies are regulated by Nigerian Co-Operative Societies Act, LFN 2004, which is a Federal Law that grants powers to the Governor of each state to establish a Directorate for Cooperatives which will be in charge of registering and regulating cooperatives.

It's also mandatory for Cooperatives to have a registered bye-law which would detail aims and objective of the society. Bye Laws ensure fairness and accountability among members and reduces abuse to barest minimum. In line with the above legal provision, ICSs could be formed to satisfy the personal financial needs of members and to provide interest free loans to meet certain contingencies. Table 1. disclosed the interview with Government Officials on the ICSs in the selected state. 
Table 1. Interview with Government Officials

\begin{tabular}{|c|c|c|c|c|c|}
\hline $\mathrm{S} / \mathrm{N}$ & Questions & Adamawa & Kwara & Zamfara & Gombe \\
\hline 1. & $\begin{array}{l}\text { Name of the Ministry } \\
\text { /Commission/Board/Agency, City } \\
\text { and State. }\end{array}$ & $\begin{array}{l}\text { Ministry of Finance } \\
\text { (Directorate of } \\
\text { Cooperatives and } \\
\text { SME's) Yola }\end{array}$ & $\begin{array}{l}\text { Kwara State Ministry } \\
\text { of Commerce and } \\
\text { Cooperative Ilorin }\end{array}$ & $\begin{array}{l}\text { Zamfara State Cooperative } \\
\text { Federation Min. for Rural } \\
\text { Development and } \\
\text { cooperatives Gusau }\end{array}$ & $\begin{array}{l}\text { Gombe State Ministry of } \\
\text { Commerce and Industry, } \\
\text { Gombe }\end{array}$ \\
\hline 2 & $\begin{array}{l}\text { When was the first year of } \\
\text { registered Islamic cooperative } \\
\text { society in the State and number that } \\
\text { registered? }\end{array}$ & $2014,(1)$ & $2008,(1)$ & $2013,(1)$ & $2010,(1)$ \\
\hline 3 & $\begin{array}{l}\text { The total number of registered } \\
\text { Islamic cooperative societies in the } \\
\text { State as at } 31 / 3 / 2021 \text {. }\end{array}$ & $\begin{array}{l}\text { In operation (3) } \\
\text { Process of } \\
\text { Registration (11) }\end{array}$ & 150 & 7 & 4 \\
\hline 4 & $\begin{array}{l}\text { The total number of registered } \\
\text { Conventional and Islamic } \\
\text { cooperative societies in the State as } \\
\text { at } 31 / 3 / 2021 \text {. }\end{array}$ & 237 & 400 & 1400 & 8650 \\
\hline 5 & $\begin{array}{l}\text { The total number of Islamic } \\
\text { cooperative societies in the State } \\
\text { that liquidated/ closedown as at } \\
31 / 3 / 2021\end{array}$ & 0 & 15 & 0 & 0 \\
\hline 6 & $\begin{array}{l}\text { What challenges are you } \\
\text { experiencing in approving } \\
\text { formation of Islamic cooperative } \\
\text { society? }\end{array}$ & $\begin{array}{l}\text { Leadership tussle, } \\
\text { Transparency \& } \\
\text { Accountability and } \\
\text { Misconduct. }\end{array}$ & $\begin{array}{l}\text { Lack of Understanding } \\
\text { Islamic Finance } \\
\text { System lead to very } \\
\text { few application }\end{array}$ & $\begin{array}{l}\text { No challenges, only the } \\
\text { level of understanding is } \\
\text { very low. }\end{array}$ & $\begin{array}{l}\text { No much challenges, only } \\
\text { that members don't want to } \\
\text { comply with bye laws } \\
\text { sometimes. }\end{array}$ \\
\hline 7 & $\begin{array}{l}\text { How are Islamic cooperative } \\
\text { societies in the State regulated and } \\
\text { supervised to ensure they operate } \\
\text { under the Islamic compliance? }\end{array}$ & $\begin{array}{l}\text { Provision of Bye- } \\
\text { law in accordance } \\
\text { with Islamic and } \\
\text { CAPC } 19 \text { law of } \\
\text { Kwara No4 of } 2006\end{array}$ & $\begin{array}{l}\text { Must compliance with } \\
\text { their Aims and } \\
\text { objective and } \\
\text { Cooperative Act } 2014\end{array}$ & $\begin{array}{l}\text { We supervised them base on } \\
\text { the approved objectives and } \\
\text { ensure compliance with } \\
\text { cooperative act } 2014\end{array}$ & $\begin{array}{l}\text { Compliance with laid down } \\
\text { Aims and objective of the } \\
\text { Cooperative Bye Law } \\
2010\end{array}$ \\
\hline 8 & $\begin{array}{l}\text { Is there any significant difference } \\
\text { in the requirements for registering } \\
\text { an Islamic cooperative society and } \\
\text { conventional cooperative society in } \\
\text { the State? }\end{array}$ & No & $\begin{array}{l}\text { Aims and Objective } \\
\text { must be Islamic } \\
\text { finance compliance }\end{array}$ & $\begin{array}{l}\text { No any significant } \\
\text { differences other than the } \\
\text { objectives of the society }\end{array}$ & No \\
\hline 9 & $\begin{array}{l}\text { In your view, are cooperative } \\
\text { linked with Islamic finance thriving } \\
\text { more than the conventional? If yes } \\
\text { how; if no why not }\end{array}$ & $\begin{array}{l}\text { Yes. Because the } \\
\text { system do away } \\
\text { with interest that } \\
\text { kills many business }\end{array}$ & $\begin{array}{l}\text { They thrives better } \\
\text { economically }\end{array}$ & $\begin{array}{l}\text { They are performing well } \\
\text { economically. }\end{array}$ & $\begin{array}{l}\text { Yes, as the system is } \\
\text { against haram dealings, } \\
\text { they thrives economically }\end{array}$ \\
\hline 10 & $\begin{array}{l}\text { How would you rate the level of } \\
\text { satisfaction on the activities of } \\
\text { Islamic cooperative society in the } \\
\text { State? }\end{array}$ & $4 / 5$ & $3 / 5$ & $5 / 5$ & $3 / 5$ \\
\hline 11 & $\begin{array}{l}\text { How would you rate the level of } \\
\text { socio-economic development } \\
\text { achieved by Islamic cooperative in } \\
\text { the past five years? }\end{array}$ & $5 / 5$ & $4 / 5$ & $5 / 5$ & $3 / 5$ \\
\hline
\end{tabular}

Source: Computed from field survey (2021)

Table 1 can be summarized as follows:

$>$ The selected four state establish a Directorate for Cooperatives which are in charge of registering and regulating cooperatives in accordance with Nigeria Cooperative Societies are regulated by Nigerian Co-Operative Societies Act, LFN 2004,

Registration of Islamic cooperatives societies (ICSs) is much recent and very few compared with conventional cooperatives societies

$>$ The performance of ICSs is better economically and can be used as tool for poverty alleviation and socioeconomic development of the societies and Nigeria in general.

The desire to establish ICSs is to help in alleviating poverty among Muslims in particular and the entire world in general through the development of Islamic economy and social values. Table 2 shows the Interview with identified Islamic cooperatives officials in the selected state. 
Table 2. Interview with Identified cooperatives Officials

\begin{tabular}{|c|c|c|c|c|c|}
\hline $\mathrm{S} / \mathrm{N}$ & Questions & Adamawa & Kwara & Zamfara & Gombe \\
\hline 1. & $\begin{array}{l}\text { Name of the cooperative } \\
\text { society, } \\
\text { City and State }\end{array}$ & $\begin{array}{l}\text { Muslim cooperative } \\
\text { society MAUTECH } \\
\text { Yola }\end{array}$ & $\begin{array}{l}\text { AL-AMIN MCS APATA } \\
\text { YAKUBA ILORIN } \\
\text { KWARA STATE. }\end{array}$ & $\begin{array}{l}\text { Legacy Halal Business } \\
\text { Cooperative Society, Federal } \\
\text { Polytechnic, Kaura Namoda, } \\
\text { Zamfara State. }\end{array}$ & $\begin{array}{l}\text { MURABAHA } \\
\text { Multipurpose } \\
\text { cooperative society } \\
\text { Gombe State University } \\
\text { Gombe State. }\end{array}$ \\
\hline 2 & $\begin{array}{l}\text { What were your objectives } \\
\text { when forming the } \\
\text { cooperative? }\end{array}$ & $\begin{array}{l}\text { To uphold Islamic } \\
\text { faith in Financial } \\
\text { status toward the } \\
\text { teaching and } \\
\text { guidance of Allah }\end{array}$ & $\begin{array}{l}\text { To create funds to be lent to } \\
\text { its members in accordance } \\
\text { with the shariah, for } \\
\text { provident and productive } \\
\text { purposes. }\end{array}$ & $\begin{array}{l}\text { To provide welfare services to } \\
\text { members and provide } \\
\text { alternative to riba (interest) } \\
\text { based financial institutions. }\end{array}$ & $\begin{array}{l}\text { The development of } \\
\text { socioeconomic and } \\
\text { educational capacity of } \\
\text { Muslim Ummah in the } \\
\text { University }\end{array}$ \\
\hline 3 & $\begin{array}{l}\text { How long have you registered } \\
\text { the cooperative society and } \\
\text { with how many members } \\
\text { during the registration? }\end{array}$ & $\begin{array}{l}\text { Registered in } 2020 \\
\text { with } 50 \text { members }\end{array}$ & $\begin{array}{l}\text { Registered in } 2019 \text { with } 30 \\
\text { members }\end{array}$ & $\begin{array}{l}\text { Registered in } 2013 \text { with } 20 \\
\text { members }\end{array}$ & $\begin{array}{l}\text { Registered in } 2010 \text { with } \\
20 \text { members }\end{array}$ \\
\hline 4 & $\begin{array}{l}\text { How many active members as } \\
\text { at } 31 / 3 / 2021 \text { ? }\end{array}$ & 270 members & 52 members & 720 members & 357 members \\
\hline 5 & $\begin{array}{l}\text { How has the conventional } \\
\text { finance system influenced the } \\
\text { running of the cooperative? }\end{array}$ & $\begin{array}{l}\text { The conventional } \\
\text { system does not } \\
\text { influence our own } \\
\text { Islamic cooperative } \\
\text { society }\end{array}$ & $\begin{array}{l}\text { People compare the two and } \\
\text { found Islamic cooperative } \\
\text { very comfortable and } \\
\text { helpful thereby increase } \\
\text { members enrollment. }\end{array}$ & $\begin{array}{l}\text { Yes, to the extent that we do } \\
\text { not accept anyone dealing with } \\
\text { conventional finance } \\
\text { institutions like banks or } \\
\text { cooperative societies. }\end{array}$ & $\begin{array}{l}\text { It has negative influence } \\
\text { because of the } \\
\text { differences in the two } \\
\text { system }\end{array}$ \\
\hline 6 & $\begin{array}{l}\text { Do you receive assistance } \\
\text { from government or any } \\
\text { donor agency, and if yes, } \\
\text { what kind of assistance? }\end{array}$ & No & None & None & No \\
\hline 7 & $\begin{array}{l}\text { How do you manage your } \\
\text { finances/proceeds? }\end{array}$ & $\begin{array}{l}\text { Direct deduction } \\
\text { from salary and } \\
\text { manage according } \\
\text { to the bye-law and } \\
\text { Islamic financial } \\
\text { law. }\end{array}$ & $\begin{array}{l}\text { Members contributions } \\
\text { according to bye-law and } \\
\text { shariah }\end{array}$ & $\begin{array}{l}\text { Through regular monthly } \\
\text { contributions by members. We } \\
\text { secured direct deduction from } \\
\text { salary from the Polytechnic } \\
\text { Management. The staff of the } \\
\text { Polytechnic forms over } 80 \% \text { of } \\
\text { our members }\end{array}$ & $\begin{array}{l}\text { It is manage according } \\
\text { to the Islamic } \\
\text { jurisprudence mainly } \\
\text { base on the members' } \\
\text { contribution deducted } \\
\text { from their salary. }\end{array}$ \\
\hline 8 & $\begin{array}{l}\text { Do you provide other socio- } \\
\text { economic benefit in your } \\
\text { cooperative and if yes what } \\
\text { kind of benefit? }\end{array}$ & $\begin{array}{l}\text { Yes. We deal with } \\
\text { sales of commodity } \\
\text { and appliance in an } \\
\text { installment and cost } \\
\text { profit margin. }\end{array}$ & $\begin{array}{l}\text { Yes, Given out part of the } \\
\text { profit made at the end of the } \\
\text { year to the less privilege in } \\
\text { the society }\end{array}$ & $\begin{array}{l}\text { Yes. We provide welfare } \\
\text { packages in terms of foodstuffs } \\
\text { especially during Islamic } \\
\text { festivals. Members pay in two } \\
\text { to four monthly instalments. }\end{array}$ & $\begin{array}{l}\text { Yes. Payment of } \\
\text { Hospital bills. }\end{array}$ \\
\hline 9 & $\begin{array}{l}\text { What impact has the } \\
\text { cooperative made in the lives } \\
\text { of your members and in the } \\
\text { community? }\end{array}$ & $\begin{array}{l}\text { It has impact } \\
\text { tremendously in the } \\
\text { Economic activities } \\
\text { of our members. }\end{array}$ & $\begin{array}{l}\text { Many member has had the } \\
\text { opportunity of acquired } \\
\text { facilities through society and } \\
\text { help them out from their } \\
\text { financial crisis thereby } \\
\text { reducing level of poverty in } \\
\text { the society. }\end{array}$ & $\begin{array}{l}\text { It has instilled financial } \\
\text { discipline in our members and } \\
\text { has made them to be contented } \\
\text { with Halal ways of financial } \\
\text { dealings devoid of interest or } \\
\text { riba. }\end{array}$ & $\begin{array}{l}\text { It has help members to } \\
\text { own house buy land, } \\
\text { buy car complete their } \\
\text { educational program and } \\
\text { improve their business } \\
\text { capital base. }\end{array}$ \\
\hline 10 & $\begin{array}{l}\text { In your view, what do you } \\
\text { think will make the } \\
\text { cooperative sustainable } \\
\text { (include challenges and } \\
\text { mitigation factors)? }\end{array}$ & $\begin{array}{l}\text { ICT Compliance. } \\
\text { Training of the } \\
\text { executive members }\end{array}$ & $\begin{array}{l}\text { Faithfulness, accountability } \\
\text { and adhering to the kitab } \\
\text { and Sunnah of the prophet } \\
\text { by the executives and } \\
\text { members }\end{array}$ & $\begin{array}{l}\text { Dedications by members and } \\
\text { officials. Recognizing that } \\
\text { peoples' money is a trust that } \\
\text { must be kept religiously. }\end{array}$ & $\begin{array}{l}\text { Absolute cooperation of } \\
\text { members to rules and } \\
\text { regulations of the } \\
\text { society and keeping up- } \\
\text { to-date financial records } \\
\text { of the society. }\end{array}$ \\
\hline 11 & $\begin{array}{l}\text { What are the future plans for } \\
\text { this cooperative? }\end{array}$ & $\begin{array}{l}\text { Providing asset for } \\
\text { members. } \\
\text { Establishment of } \\
\text { Microfinance Bank }\end{array}$ & $\begin{array}{l}\text { To promote the economic } \\
\text { interest of members. To } \\
\text { attain level of having our } \\
\text { own bank }\end{array}$ & $\begin{array}{l}\text { To expand our business and get } \\
\text { more benefits to members. }\end{array}$ & $\begin{array}{l}\text { Open an Islamic } \\
\text { Microfinance Bank. }\end{array}$ \\
\hline
\end{tabular}

\section{Source: Computed from field survey (2021)}

Table 2 can be summaries as follows:

$>$ The general aims and objectives of identifies Islamic cooperative societies (ICSs) is to do away with interest base economic and operate in accordance with Shari'ah.

Membership of ICS are on increase which is an indication of acceptance by the societies 
No assistance was received from government or any donor agency by any of the identified Islamic cooperative societies.

$>$ The general future plan of identified ICSs is to Establish Islamic Microfinance Bank

The un-Islamic nature of conventional cooperatives and the need to engage in economic activities for economic improvements according to the Sharī $a h$ suggest the formation or joining of one cooperative or the other by the Muslims, which they term as Islamic Cooperative Society (ICS). Descriptive statistics was used to achieve the objective of describing the Bio data/socio-economic characteristics and response to topical issues of the respondents of ICSs through the use of percentages

Table 3. Bio data and socio-economic characteristics of respondent

\begin{tabular}{|c|c|c|c|c|c|c|}
\hline 1 & Religion & $\begin{array}{l}\text { Muslim } \\
177 \quad 96.72 \%\end{array}$ & \begin{tabular}{l}
\multicolumn{2}{l}{ Christian } \\
$4 \quad 2.45 \%$
\end{tabular} & $\begin{array}{l}\text { Others } \\
2\end{array}$ & & $\begin{array}{c}\text { Total } \\
183\end{array}$ \\
\hline 2 & Gender & $\begin{array}{ll}\text { Male } & \\
142 & 77.60 \% \\
\end{array}$ & $\begin{array}{ll}\text { Female } & \\
41 & 22.40 \% \\
\end{array}$ & & $\begin{array}{c}\text { Total } \\
183 \\
\end{array}$ & \\
\hline 3 & State of Residence & $\begin{array}{l}\text { Adamawa } \\
7 \quad 3.83 \% \\
\end{array}$ & $\begin{array}{l}\text { Gombe } \\
74\end{array}$ & $\begin{array}{l}\text { Kwara } \\
45\end{array}$ & $\begin{array}{ll}\text { Zamfara } \\
19 \quad 10.58 \% \\
\end{array}$ & $\begin{array}{l}\text { Others } \\
38 \quad 20.76 \%\end{array}$ \\
\hline 4 & Employment & $\begin{array}{l}\text { Employed } \\
141 \quad 77.05 \%\end{array}$ & $\begin{array}{l}\text { Self-employed } \\
38 \quad 20.77 \\
\end{array}$ & $\begin{array}{l}\text { Unemployed } \\
4 \quad 2.18 \% \\
\end{array}$ & $\begin{array}{l}\text { Total } \\
183 \\
\end{array}$ & \\
\hline 5 & Scale of Business Operation & $\begin{array}{l}\text { Civil Servant } \\
134 \quad 73.22 \% \\
\end{array}$ & $\begin{array}{lr}\text { Micro Business } \\
6 & 3.28 \% \\
\end{array}$ & $\begin{array}{l}\text { Small } \\
15 \\
\end{array}$ & $\begin{array}{ll}\text { Medium business } \\
28 & 15.3 \% \\
\end{array}$ & \\
\hline 6 & Financial Capital Base & $\begin{array}{l}\text { Civil Servant } \\
134 \quad 61.75 \% \\
\end{array}$ & $\begin{array}{l}100,000-1 \text { Million } \\
52 \quad 28.42 \% \\
\end{array}$ & $\begin{array}{l}\text { Above 1Million Les } \\
\text { 2Million } \\
5\end{array}$ & $\begin{array}{l}\text { Above } 2 \text { Million } \\
13 \\
\end{array}$ & \\
\hline 7 & $\begin{array}{l}\text { How long have you been operating } \\
\text { With Islamic Cooperative Society }\end{array}$ & $\begin{array}{l}1-5 \text { Years } \\
97 \quad 53 \%\end{array}$ & $\begin{array}{lr}6-10 \text { Years } \\
63 \quad 34.43 \% \\
\end{array}$ & $\begin{array}{lr}\text { Above } & 10 \text { Years } \\
23 & 12.57 \% \\
\end{array}$ & $\begin{array}{l}\text { Total } \\
183 \\
\end{array}$ & \\
\hline
\end{tabular}

Source: Computed from field survey (2021)

Table 3 shows bio data and socio-economic characteristics of the respondents of Islamic cooperatives societies. It shows that for religion, majority of the respondents are Muslim (96.72\%), with $73.22 \%$ of the respondent Civil Servant. That may be in connection with the fact that Civil servant has regular income that make managing their contributions easier. Findings from table 1 similarly revealed that greater percentage started operating with ICS not more than 10 years ago, an evidence that ICSs is new in Nigeria particularly the selected states.

Table 4. Response on topical issues

\begin{tabular}{|c|c|c|c|c|c|c|}
\hline & & Ye: & $\%$ & No & $\%$ & Total \\
\hline 1. & $\begin{array}{l}\text { Your aim of joining Islamic cooperative } \\
\text { is for investment and saving purposes }\end{array}$ & $17 \%$ & 93.9! & 11 & 6.0 & 183 \\
\hline 2 & $\begin{array}{l}\text { Your purpose of joining the Islamic cooperative } \\
\text { is to have access to fund (borrowing) }\end{array}$ & 12( & 65.5 & 43 & 34.4 & 183 \\
\hline 3 & $\begin{array}{l}\text { Have you operated conventional cooperative } \\
\text { Society before? }\end{array}$ & 73 & 39.85 & 110 & 60.1 & 183 \\
\hline 4 & $\begin{array}{l}\text { Do you consider Islamic cooperative } \\
\text { Society a reliable source of finance? }\end{array}$ & $17 t$ & 96.1' & 7 & 3.8: & 183 \\
\hline 5 & $\begin{array}{l}\text { Do you have idea on the concept of } \\
\text { Islamic cooperatives Societies? }\end{array}$ & $14:$ & 79.2 & 38 & 20.7 & 183 \\
\hline 6 & $\begin{array}{l}\text { Your cooperative society operates under } \\
\text { Islamic compliance }\end{array}$ & 17 : & 95.6 & 8 & $4.3^{\prime}$ & 183 \\
\hline 7 & $\begin{array}{l}\text { You often receive a dividend on investments } \\
\text { from your Islamic cooperative }\end{array}$ & 15: & 85.7 & 26 & 14.2 & 183 \\
\hline
\end{tabular}




\begin{tabular}{|c|c|c|c|c|c|c|}
\hline 8 & $\begin{array}{l}\text { You often receive socio-economic benefit } \\
\text { from your Islamic cooperative }\end{array}$ & 16( & 87.4: & 23 & 12.5 & 183 \\
\hline 9 & $\begin{array}{l}\text { You will continue to operate with Islamic cooperative e' } \\
\text { you don't receive a dividend on investment. }\end{array}$ & 159 & 86 & 24 & 86.89 & 183 \\
\hline 10 & $\begin{array}{l}\text { You will opt for a conventional cooperative } \\
\text { that give much returns on investments }\end{array}$ & 36 & $19.6^{\circ}$ & 147 & 80.3 & 183 \\
\hline 11 & $\begin{array}{l}\text { Service charges of your Islamic cooperative are } \\
\text { high compared to conventional cooperatives }\end{array}$ & 23 & $12.5^{\circ}$ & 160 & 87.4 & 183 \\
\hline 12 & $\begin{array}{l}\text { Your cooperative always give you necessary } \\
\text { information about a transaction you want to carry out }\end{array}$ & 161 & 86.51 & 22 & 13.5 & 183 \\
\hline 13 & $\begin{array}{l}\text { Finances/Proceeds are properly managed by your Islami } \\
\text { cooperative society. }\end{array}$ & 173 & 94.5 & 10 & 5.46 & 183 \\
\hline 15 & $\begin{array}{l}\text { An Islamic cooperative is a third and new way } \\
\text { between capitalism and socialism }\end{array}$ & $\begin{array}{l}\text { Agree } \\
141\end{array}$ & $\begin{array}{c}\% \\
77.0\end{array}$ & $\begin{array}{l}\text { Disagree } \\
42\end{array}$ & $\begin{array}{r}\% \\
22.9\end{array}$ & $\begin{array}{l}\text { tal } \\
183\end{array}$ \\
\hline 16 & $\begin{array}{l}\text { Islamic cooperative societies contributes to human } \\
\text { prosperity, social balance and welfare. }\end{array}$ & 183 & 100.0 & 0 & 0.06 & 183 \\
\hline
\end{tabular}

Source: Computed from field survey (2021)

Table 4 shows the results of the respondents of ICSs on the topical issues raised in the research, majority of the respondents' response is positively infavour of ICSs in terms of reliability, operation, provision of socio-economic benefits and less service charges.

\section{CONCLUSION AND POLICY RECOMMENDATIONS}

The concept of Islamic co-operative societies as it is being practiced in other countries is comparatively new in Nigerian society, and thus it has not been fully understood even by many Nigerian Muslims.

Consequently, there is a need for both Muslims and non-Muslims to be informed on how the practices of Islamic Co-operative in Nigeria differ from conventional ones especially in their operations to provide the incentive needed for conventional co-operative members to consider establishing Islamic co-operative.

The study noted that Islamic cooperative societies provide essential commodities to members at appropriate prices thereby enabling them to consume goods they would ordinarily not have been able to consume. They also encourage members to save and give interest free credit facilities to the needy members. All these help the standard of living of members to improve considerably and eventually with multiplier effect on the sustainability of the society and the country at large.

The study recommended that Islamic cooperative society should be opened to all and sundry irrespective of religion belief. Islamic co-operative has no religious inbuilt discrimination and its products are available and accessible to anybody regardless of belief. However, ICSs indeed have religious considerations. Non-Muslims can only be encouraged to have non-interest based cooperatives, because based on their beliefs, non-Muslims may want to engage in other activities not allowed by Islam like sales of alcohol, pigs etc. It is also recommended that Islamic finance scholars and operators should promote and enhance Islamic cooperative activities and participation through large scale and aggressive campaign, organize seminars, symposia, workshops and conferences by inviting experts in Islamic economic system in order to educate members and nonmembers of cooperatives about the contributions of Islamic cooperatives to the social and economic wellbeing of the common man, especially in the area that can help in alleviating poverty.

All bureaucratic impediments militating against the establishment and development of ICSs in Nigeria should be minimized by government at all level. It is therefore recommended that the Governments at various levels (Local, State and Federal) are expected to provide a supportive policy, legal and institutional framework, provide support measures based on activities. More so, Government should aid and encourage these organizations to enable them stand and perform 
effectively through human capacity development workshops and seminars since they are established to enhance human livelihood and economic development of Nigeria in general.

\section{REFERENCES}

Abubakar A. M., (2020). Application of Islamic Financing Options in the Operations of Yobe State Cooperative Multi-Purpose Society (YSU-CMS). Journal of Islamic Business and Economic Review 3(1), 31-37

Ahmad A. U. F., \& Ahmad, A. R. (2008). Islamic microfinance: A case study of Australia. Journal of Islamic Economics, Banking and Finance, (2), 59-80.

Ajani M. A. A., \& Adebayo R. I (2018). An examination of the sources and expenditures of funds in the Islamic cooperative societies in Nigeria. Ilorin Journal of Religious Studies, (IJOURELS), 8 (2), 35-50

Azeez, A. O., \& Salako, T. A. (2007). Practicability of Islamic Economic Theories to Poverty Alleviation: Alamsek Press Limited. 339-348.

Blewitt, J. (2008). Understanding Sustainable Development. (1 ${ }^{\text {st }}$ ed.) UK. London. Earthscan Publication Ltd.

Chapra, U. (2008).The Islamic vision of development in the light of maqasid al-Shariah. Islamic Research and Training Institute, Islamic development Bank.

Dusuki, A., \& Abozaid, A. (2007). A critical appraisal on the challenges of realizing Maqasid al-Shariah in Islamic Banking and Finance. IIUM Journal of Economics and Management, 15(2): 143-165

El-Mesawi, M. (2006). Ibn Ashur Treatise on Maqasis al Shariah, The International Institute of Islamic Thought London.

Graaff, J. (2003). Introductions to sociology: Poverty and Development. Oxford Cape Town. University Press

Irfan Beik \& Indah Purnamasari. (2011). Role of Islamic Cooperatives in Financing Micro and Small Scale Entrepreneurs in Indonesia: Case Study of KOSPIN Jasa Syariah Pekalongan. Paper presented at the Eight International Conference on Islamic Economics and Finance. Organized by Qatar Faculty of Islamic Studies and the Qatar Foundation on 19th -21th December 2011, Doha Qatar

Islam, K. M. A. (2017). Finance: An Islamic Perspective. International Journal of Islamic Banking and Finance Research, 1(1), 1-5. https://doi.org/10.46281/ijibfr.v1i1.32

Kareem, R.O, Arigbabu, Y.D, Akintaro, J.A. \& Badmus, M.A (2012). The impact of cooperative society on capital formation: A case study of Temidire Cooperative and Thrift Society Ijebu Ode Ogun State Nigeria, Global Journal of Science Frontier Research Agriculture and Veterinary Sciences 12(11): 17-23

Mohammed, A. \& Hasan, Z. (2008) Microfinance in Nigeria and the Prospects of Introducing an Islamic Version in the Light of selected Muslim countriese experience, Review of 


Islamic Economics,
muenchen.de/8127/1/MPRA_paper_8127.pdf 13(1) https://mpra.ub.uni-

Nigerian Cooperative Societies Act, LFN 2004.

Nwagbara, C. (2018), Relevance of Cooperative Societies to the Nigerian Economy - A Legal Approach International Journal of Innovative Legal \& Political Studies 6(2): 38-56

Onakoya, A.B. \& Onakoya, A. O. (2013). Islamic microfinance as a poverty alleviation tool: Expectations from Ogun State, Nigeria Scholarly Journals 2013: 36-39

Swanepoel, H. (1992). Community Development: Putting Plans into Action (2 ${ }^{\text {nd }}$ edition). Kenwyn. Juta.

Yusuf, A. D., \& Ahmad Razimi, M. S. (2017). Nigerian Economic Recession: An Islamic Perspective. International Journal of Islamic Banking and Finance Research, 1(1), 613. https://doi.org/10.46281/ijibfr.v1i1.34

\section{Copyrights}

Copyright for this article is retained by the author(s), with first publication rights granted to the journal. This is an open-access article distributed under the terms and conditions of the Creative Commons Attribution license (http://creativecommons.org/licenses/by/4.0/) 